\title{
Balance Strategies of Production Logistics Based on Flexible Production
}

\author{
Li-Jun Zhou ${ }^{1}$ \\ ${ }^{1}$ Nanjing Institute of Industry Technology, Nanjing, China \\ Correspondence: Li-Jun Zhou, Nanjing Institute of Industry Technology, Nanjing 210023, China.
}

Received: December 14, 2017

Accepted: January 17, $2018 \quad$ Online Published: February 26, 2018

doi:10.20849/abr.v3i1.315

URL: https://doi.org/10.20849/abr.v3i1.315

\begin{abstract}
Flexible production is implemented effectively on the condition that production logistics is kept in balance. The paper starts with the analyses of the balanced factors of logistics for flexible production, then, furthers to discuss how to balance production logistics. The conclusion can be drawn that the improvement of the load rate, balance rate of the production, and the executive rate of the contract is the purpose of balance logistics for flexible production and the main contents of logistics balance while keeping the balance of production line, identifying bottlenecks resources, compiling production planning and setting buffer links are the key means and effective measures of balancing production logistics.
\end{abstract}

Keywords: flexible production, mixed production line, bottlenecks resources, production planning, buffer link

\section{Preface}

Flexible production is defined as a new mode of production to organize production according to customer orders and market demands. There is no order, no production, neither is demand. Its key advantage is that various consumers' needs are satisfied so as to make full use of resources, minimize waste, reduce costs, shorten the production cycle thus enhancing the flexibility and adaptability of the enterprise and dramatically improving its core competitiveness. However, the enterprise with flexible production is subject to the buyer's market needs but the customer's needs are characterized by diversification and individualization so the product life cycles come to shorten and the competition of the market becomes fierce. So the enterprise needs to adjust production plan and implementation programs according to the changes in the market with the result that the production appears to be volatile and passive. Correspondingly, production logistics appears to be random and uncertain, which requires that the enterprise should establish a set of balance strategies mechanism of production logistics which adapt to flexible production so as to effectively carry out flexible production.

\section{Status Quo}

Concerning the problems of production logistics balance, some scholars have conducted researches from different perspectives. David (2001) put forward its solution mainly from three respects: first, the impact of production process on logistics route; second, the demand of production capacity for logistics facilities and equipment; third, the impact of production rhythm on logistics volume.

Cetinkaya (1998) stood for the belief that production logistics management should meet the following requirements in order to ensure its stability, namely: continuous production (goods are proceeded through each link with its inherent technological process with little or without unnecessary interruption); matching of production capacity (on production capacity, there is an appropriate ratio between each interval of production process and each process. When the capacity imbalance, measures should be taken to adjust or coordinate); balanced production (i.e., through each link of production, a substantially equal or gradually increasing number of products are made during the same period so as to keep the work load of each link relatively stable) and parallelity of production process (i.e., materials are used in parallel for the operation of each link so as to improve labor productivity).

Eric Noreen (2006) emphasized that production logistics balance should start with the standardization of enterprise infrastructure management to establish and improve the optimization index system of production and logistics. In order to achieve the above-mentioned objectives of production logistics management, it is necessary to make reasonable production and operation plans, optimize production planning, strengthen production and 
logistics control and improve the management of WIP inventory and in-plant transportation based on basic data.

Rose Warren (2009) proposed five measures to achieve the balance of production logistics: firstly, through the establishment and gradual improvement of production and logistics optimization index system and production planning optimization system (including the standardization of production planning processes, the varieties optimization based on the prediction of market and production optimization, etc.), solve the problems of production management planning and production scheduling planning. Secondly, by strengthening the process control of production and logistics process, solve such problems as production planning optimization formation, logistics tracking and production scheduling. Thirdly, establish integral material supply management system use pull inventory management methods and principles and thoroughly improve the traditional inventory management model. Fourthly, through the reset of enterprise process, improve logistics management system and set an independent specialized logistics management department so as to regulate the entire production logistics management process and cut back overstaffing organization. Fifthly, accelerate the pace of enterprise informalization and establish its logistics management information system.

Yang Heng, Han Wen-min and Han bing-jie (2010) argued that in order to achieve the balance of production logistics, it is necessary to implement the optimal planning and control, Accordingly, they proposed three strategies for balancing production logistics: First, build production logistics balance model to set the batch size and lead time of production system; second, analyze various factors that may affect the work of the bottleneck properly in the system, thus setting the model of buffer size; third, utilize "funnel model" and two DBR production control model, thus establishing production control model under restricted conditions. They explore the balance of production logistics from the perspective of product portfolio.

Based on the tray management tools, Li Wen-jing, Tang Qian and Li Wei-hua (2009) applied optimal mathematical model of facility layout to analyze the role of tray management in the facility layout planning and discuss the impact of different production logistics system with the objective of minimalization of material handling cost between facilities, cost-effectiveness, time-effectiveness, quality efficiency, zero inventory, zero defect, thus setting the optimal planning of workshop layout for balancing production logistics from the perspective of workshop layout.

Tang Yin-ying, Peng Qi-yuan et al. (2007) drew on the related ideas of LSI design, put forward representation of facility layout coding based on ordered tree. Then according to the relationship among the arrangement, the constraint graph and O-tree, they give algorithm of basic layout by setting area utilization rate as the objective function. By the O-tree coding of arrangement, they use the complex facility layout to solve the problems of spatial mapping and simple coding space so that complex facility layout is converted to a relatively simple coding problem, thereby optimizing the performance-driven facilities.

Li Hong-ying, Zhu Hua-bing, Song Shou-xu et al. (2005) discussed the influence of different layout programs on production logistics system based on the facility layout optimization mathematical model with the objective of minimizing material handling cost, in combination with a certain manufacturer layout program, thus setting its planar layout optimal program.

As above-mentioned, the research conducted by the scholars on the balance of production logistics contributes a lot to the optimization of enterprise's production logistics system, the further reduction of logistics costs and the improvement of its competitiveness. But overall, there are still some problems, the most prominent is that the research by most scholars is conducted from static perspectives so that the research on the dynamic integral relevance of production logistics system is not enough. Especially, only a few scholars research logistics system problems in combination with different modes of production and analyze the logistics operation mechanism under different modes of production. Whatsoever, few scholars focus on production logistics balance from the perspective of flexible production. So the relevance and applicability of the existing research should be emphasized. It deserves our further study.

To bring flexible production into full play in such aspects as reducing costs, the use of resources, the satisfaction of individual needs of customer, the enhancement of enterprise core competitiveness and the achievement of the goal of low-carbon economy, meanwhile, to give guidance on the implementation of flexible production of our enterprises, promote China's manufacturing industry sustainable development, enhance their competitiveness and achieve harmony between human being and nature, the article focuses on the production logistics balance under flexible production with the intention to build the balance strategies mechanism to meet flexible production under the guidance of the scientific concept of development and with the integrated use of the knowledge and methods of systems science, management science and information science 


\section{Content of Production Logistics Balance under the Flexible Production}

The aim of balancing logistics under flexible production is to balance production and make full-load production so as to fulfill customer orders. And therefore, the content of logistics balance is to increase the load rate and balance rate of production, and the completion rate of contract.

\subsection{Load Rate of Production}

Load rate of production refers to the ratio between logistics volume and production capacity in a certain period of production, which shows the load situation in the period. When the ratio tends to 1 , it indicates that the production tends to full load; when the ratio deviates from 1, it indicates that the production tends to small load.

\subsection{Production Balance Rate}

Production balance rate means the ratio between logistics volume in a certain period of production and the average production capacity in all logistics stages of production lines, which can reflect the balance situation of the material in various stages of production logistics. When the ratio tends to 1 , it indicates that the logistics tends to be evenly distributed in the period as opposed to production line; when the ratio deviates from 1, it indicates that the logistics tends to be unevenly distributed in the period as opposed to production line.

\subsection{Contract Completion Rate}

The ultimate goal of logistics balance based on flexible production is to achieve the completion rate of $100 \%$ in the number of contracts and delivery. But, due to the influence from external and internal unstable factors of the production system, generally, the actual contract completion rate tends to be $100 \%$. Only on the condition that the contract completion rate tends to $100 \%$ does the balance between logistics resources and production capacity based on flexible production make sense.

\section{Strategy of Keeping Production Logistics Balance under Flexible Production}

\subsection{Keeping Production Line Balance - Basis of Production Logistics Balance}

The most notable feature of production logistics is its close relationship with its production. Only if the production process is kept in a state of balance, the logistics is in such a state. However, production is conducted through its lines. To keep production process balance, the first step is to keep its line balance so as to ultimately achieve a balance of logistics.

Flexible production is subject to multi-species mixed one in general, i.e. for production line, a number of varieties shall be produced at the same time according to a certain production order. This feature defines that the balance of flexible production line is more complex than that of general one. According to the characteristics of mixed production, to keep it balance, the first is to scientifically set the cycle time of production line. The second is to accurately calculate the number of working station. The last is to set a good production order, which makes the logistics and production simultaneously, thus achieving the balance of variety production and further achieving the logistics balance of the entire production line.

\subsubsection{Setting Cycle Time of Mixed Production Line}

Here, cycle time refers to the interval between two identical products produced, which indicates the speed of the production line or the productivity. So it is the basis of setting production logistics volume. The number of cycle time depends on the quantity of production task in the plan and the time of finishing the task. So different from the setting of the cycle time of general production lines, that of mixed one is only calculated by the group of products as follows,

$$
\mathrm{r}=\frac{F}{\sum_{\mathrm{i}=1}^{\mathrm{p}} Q_{\mathrm{i}}}
$$

In the equation, $\mathrm{F}$ is the effective working hours in the planning period; $\mathrm{r}$ is the cycle time of mixed production line; $\mathrm{Q}_{\mathrm{i}}$ is the production of the $\mathrm{i}$-th product on the mixed production line; $\mathrm{P}$ is the number of variety (here, in the time of $F, P$ pieces of varieties are produced).

\subsubsection{Calculating Minimum Number of Working Station in Mixed Production Line}

As mentioned above, the balance of the production line depends on how to arrange production line station, namely set the number of stations. That is, in the production line, how many working stations should be set? If there are too many working stations, the production line will inevitably be lengthened, and the number of the working people will increase, which means there are more products in the production line, thus increasing the 
cost of production. Therefore, the minimum number of working stations should be calculated accurately to meet the production needs.

Set the total of the working hours of the $\mathrm{i}$-the product as $\mathrm{T}_{\mathrm{i}}$ so its total in the planning period (L) can be calculated as follows,

$$
L=\sum^{\mathrm{p}} Q_{\mathrm{i}} T_{\mathrm{i}}
$$

The minimum working stations in the mixed production line can be calculated as:

$$
N_{\min }=\left[\frac{\sum_{\mathrm{i}=1}^{\mathrm{p}} Q_{\mathrm{i}} T_{\mathrm{i}}}{\mathrm{r} \sum_{\mathrm{i}=1}^{\mathrm{p}} Q_{\mathrm{i}}}\right]
$$

\subsubsection{Balancing Mixed Production Line}

In the production of mixed production line, for different products, the essential job elements are not exactly same so cycle time can't be regarded as the standard to synchronize the process but the total operation time in planning period can do.

Set the job element $\mathrm{j}$ has the amount of work $\mathrm{t}_{\mathrm{ij}}$ for variety $\mathrm{i}$. The equation $\mathrm{t}_{\mathrm{ij}}=Q_{\mathrm{i}} \delta_{\mathrm{ij}} \mathrm{t}_{\mathrm{j}}$

Among them, $\delta_{\mathrm{ij}}=\left\{\begin{array}{l}1, \text { Varietyineedgothroughtheelement } j \\ 0\end{array}\right.$

The total operation time of job element $\mathrm{j}$ in planning period is

$$
L_{\mathrm{j}}=\sum_{\mathrm{i}=1}^{\mathrm{p}} \mathrm{t}_{\mathrm{ij}}=\sum_{\mathrm{i}=1}^{\mathrm{p}} Q_{\mathrm{i}} \delta_{\mathrm{ij}} \mathrm{t}_{\mathrm{i}}
$$

Set $\mathrm{Li}$ as the operation time of job elements and the planned effective working hours $\mathrm{F}$ as cycle time $\mathrm{r}$. The balanced method for the production line of a single object can be adopted to balance the mixed production line.

\subsubsection{Setting the Order of Mixed Production Line}

The purpose of setting the order of mixed production line is to achieve the balance of production varieties, which can be calculated through production proportion reciprocal. Set the three products A, B and C in the production line and the yields in the planning period as 6000, 4000 and 2000. The order of production can be set as follows,

First, calculate the production ratio Xi. According to the yields of the three products in the planning period, the greatest common divisor is found so as to calculate the production ratio of each variety (also called mixing ratio) $\mathrm{Xi}$. With 2000 as a case, the greatest common divisor is 2000 so the production ratios of three varieties are as follows respectively,

$$
X_{\mathrm{a}}=\frac{6000}{2000}=3, \quad X_{\mathrm{b}}=\frac{4000}{2000}=2, \quad X_{\mathrm{c}}=\frac{2000}{2000}=1
$$

In addition, the sum of the production ratio $\sum X_{\mathrm{i}}$ is regarded as the production batch of cyclic process, and the yield of a cyclic process. In this case the formula: $3+2+1=6$.

Second, calculate production ratio reciprocal mi.

$$
\mathrm{m}_{\mathrm{a}}=\frac{1}{X_{\mathrm{a}}}=\frac{1}{3}, \mathrm{~m}_{\mathrm{b}}=\frac{1}{X_{\mathrm{b}}}=\frac{1}{2}, \mathrm{~m}_{\mathrm{c}}=\frac{1}{X_{\mathrm{c}}}=1
$$

The above results shall be recorded in each variety of the first row of calculations column of Table 1 .

Third, select varieties. There are three rules: Rule one, from all products, the one with the minimum of production ratio reciprocal shall be selected. Rule two, if there are multiple varieties with a minimum, select the one with a later identification mark. Rule three, after the selection, if the variety is still the same, select the one with a penultimate late identification mark. The selected variety $\mathrm{m}_{\mathrm{i}}$ shall be marked ${ }^{*}$ as the risk.

Fourth, Update $\mathrm{m}_{\mathrm{i}}$ value. The numerator of $\mathrm{m}_{\mathrm{i}}$ value for the selected variety $\mathrm{i}$ in the third step adds 1 until $\mathrm{m}_{\mathrm{i}}$ value is equal to 1 . 
According to the above rules, all chain varieties shall be selected so far and the order of production is ABABAC

Table 1. Schedule the order of production with production ratio reciprocal method

\begin{tabular}{lllll}
\hline \multirow{2}{*}{ Calculation } & Item & \multicolumn{3}{l}{ Chain } \\
\cline { 2 - 4 } & A & B & C & \\
\hline 1 & $1 / 3^{*}$ & $1 / 2$ & 1 & A \\
2 & $2 / 3$ & $1 / 2^{*}$ & 1 & AB \\
3 & $2 / 3^{*}$ & 1 & 1 & ABA \\
4 & 1 & $1^{*}$ & 1 & ABAB \\
5 & $1^{*}$ & & 1 & ABABA \\
6 & & & $1^{*}$ & ABABAC \\
\hline
\end{tabular}

Note: * identification mark

\subsection{Identifying Bottleneck Resources - This Is the Key to Balance Production Logistics}

What are called bottleneck resources? After the comparison is made between the production tasks and capacity in planning period, the weakest sector in capacity is called bottleneck one and the resources involved are bottleneck ones. "Bottleneck" sector affects production schedule. It is only when "bottleneck" sector can operate with full load that enterprises shall achieve maximum production rate. Therefore, "bottleneck" sector is a key factor of the production constraints. And the key of production planning period management and control of enterprises is to find out the "bottleneck" sector, then plan and form it. The resources are fully utilized on the sector and allocated on the non-bottleneck sectors so as to make them keep pace, thus reducing the lowest level in overstocked products, shortening the production cycle, reducing inventory costs and make production logistics balance.

Bottleneck resources can be people, process equipment, transport capacity, market demand and materials, etc. bottleneck resources discussed in this article refer to the production capacity of the equipment, because the production capacity of the equipment is the most common major constraint in the production process.

\subsubsection{Describing Bottlenecks from the Perspective of Mathematics}

For $\mathrm{n}$ resources in the system X1, X2 .. Xn, set actual output capacity $\mathrm{C} 1, \mathrm{C} 2 \ldots \mathrm{Cn}$ and the external demands of the system MR1, MR2... MRn. There is a relationship R of mutual input and output among some resources. Suppose the set which resource $\mathrm{Xi}$-related resources are collected into as $\mathrm{S}$, then

$$
S=\left\{\mathrm{j} \mid \mathrm{j} \neq \mathrm{i} \wedge \exists \mathrm{R}\left(X_{\mathrm{i}}, X_{\mathrm{j}}\right)\right\}
$$

Resources $\mathrm{X}_{\mathrm{i}}$ is defined as bottleneck ones and only $C_{\mathrm{i}}=\leq \min \left\{M R_{\mathrm{i}}, \min \left\{\forall C_{\mathrm{j}}, \mathrm{j} \in S\right\}\right\}$

Namely the capacity $\mathrm{Ci}$ of bottleneck resources Xi can't meet its external demand MRi and the capacity $\mathrm{Cj}$ of the resources which has the relationship with its input and output is also greater than $\mathrm{Ci}$.

\subsubsection{Identifying Bottleneck Resources}

The identification of bottleneck resources can be divided into two phases. The first stage is to check the total load in the planning period according to the device group. Then the comparison is made with the capacity of the device group to check if there is a weak sector in capacity from the perspective of the total. If the load has exceeded or is close to the capacity, the measure shall be taken to improve the capacity of the device group to ensure that the planned tasks can be completed.

The second stage is to search if there are bottlenecks in each device group in each stage of planning period. The specific steps are as follows,

Firstly, calculate the latest completion date of each part and each process. The calculating method can refer to the inverse process sequence inverted one. Namely, the delivery date in the contract, the completion date of general assembly and subassembly, etc. are inverted to calculate the latest completion date of each part and each process. The equation is,

$$
T_{\mathrm{ij}}=T_{\mathrm{j}}-\sum_{\mathrm{i}+1}^{\mathrm{n}} \mathrm{t}_{\mathrm{ij}}-\sum_{\mathrm{i}+1}^{\mathrm{n}-1} \mathrm{t}_{\mathrm{t}} \mathrm{r}-\sum_{\mathrm{n}+1}^{\mathrm{n}-1} \mathrm{t}_{\mathrm{c}} \mathrm{h}
$$


Among them, $T_{i j}$ is the latest completion date of the i-th process of a certain workpiece on the equipment $j . T_{j}$ refers to the latest completion date for it (the latest delivery date allowed). $t_{\mathrm{ij}}$ stands for its processing time of the $i$-th process on the equipment $j(i 1,2,3, \ldots, n) . \sum_{i+1}^{n} t_{i j}$ represents the sum of its processing time from step $i+1$ to $n$; $\sum_{i+1}^{n-1} t_{t} r$ the sum of its processing time from step to $n-1 ; \sum_{n+1}^{n-1} t_{c} h$ the sum of its inspecting time from step $i+1$ to n-1

Secondly, set device group as a unit to collect the processing parts in it respectively. And each device group shall define the parts set $\left(\mathrm{V}_{\mathrm{j}}\right)$ in it $(\mathrm{J})$. All parts in the parts set $\left(\mathrm{V}_{\mathrm{j}}\right)$ shall be sorted according to the order of the latest completion date on $\mathrm{j}$ process. If the latest completion date is same, more processes are prior on the process. Here a sequence $T_{1 j}, T_{2 j}, T_{3 j} \ldots T_{m j}$ can be made with $m$ represents that there are $m$ parts processed on $J$ equipment.

Thirdly, for each device group, with load accumulation method, calculate the cumulative load of each time point. Its approach is to make comparison between the capacity of the device group and cumulative load from the beginning of planning period to the time point to calculate the load ratio of the device and check if it exceeds specified value so as to identify whether the device group becomes bottleneck resources before the time point. Accordingly, from the beginning to the end of planning period, as every period goes on, calculated is its corresponding cumulative load, which is compared with the production capacity in the same period so as to identify whether there are bottlenecks in the whole production process. The above-mentioned method of identify bottlenecks is shown in Figure 1.As can be seen from Figure 1, the area A at its lower left corner represents the confirmed production capacity which has been occupied in production plan. The dotted line S refers to the beginning time of the planning period and $\mathrm{E}$ its end time. The period from $\mathrm{S}$ to $\mathrm{E}$ is divided into 10 intervals. And the area below the horizontal line of production capacity and above area A is the capacity available of device group $\mathrm{J}$ in the planning period. Among them, in the first interval, the tasks that shall be completed are J1 and $\mathrm{J} 2$ with the capacity greater than load so device group $\mathrm{J}$ is not bottleneck before the end of the first interval. The tasks that shall be completed are J1, J2, J3 and J4 before the end of the second interval with capacity greater than load so device group $\mathrm{J}$ is not bottleneck before the end of the second interval. Area B means the spare capacity of device group $J$ from interval 1 to interval 5 . In interval 6 , the newly added load exceeds its production capacity. However, J13, J14, J15, J16 can be put into production in advance because the latest completion time of these parts is the end of interval 6 . Considering that the earliest start time is not defined, the production shall be arranged in advance, so the spare capacity of the previous interval shall be used. The situations in intervals 7,8 and 9 are same as those in interval 6. If the load (area $\mathrm{C}$ as shown above the production capacity line) which has exceeded the production capacity in the intervals is equal or very close to the spare capacity of device group $\mathrm{J}$ in the previous intervals and in interval 10, there is spare capacity (area D), which is not available before interval 10 because the previous tasks are bound to completed before their latest completion times, that is, they shall be completed before the end of the interval. This is because there are still bottlenecks in the production process of planning period though the production capacity is greater than the total loads.

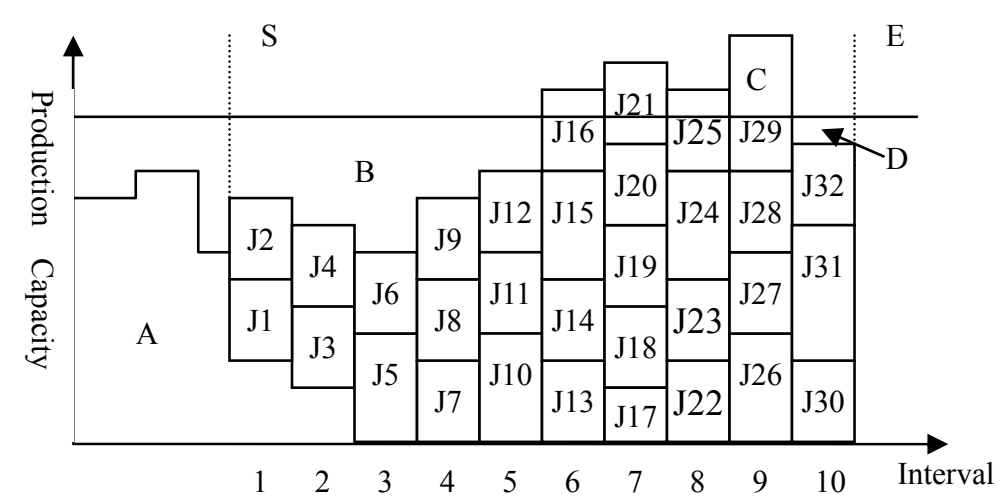

Figure 1. Loads of certain device group in planning period 


\subsection{Preparing Production Plan - Important Condition for Production Logistics Balance}

Production plan is the basis of production activities. Whether it is feasible shall directly affect the balance of production and logistics. Its feasibility depends on the balance between the load of bottlenecks processes and their capacity but is affected by the balance between the load of the entire production system and its capacity. Therefore, the compilation of a good production planning is essential to balance the logistics.

Due to bottlenecks resource constraints in the production system, in the compilation of production plans, to start with, the production plan of the critical parts of using bottleneck resources shall be laid out. On the premise of defining the schedule of critical parts, then the production plan of noncritical parts shall be laid out. The process of the compilation of production plan is shown in Figure 2.

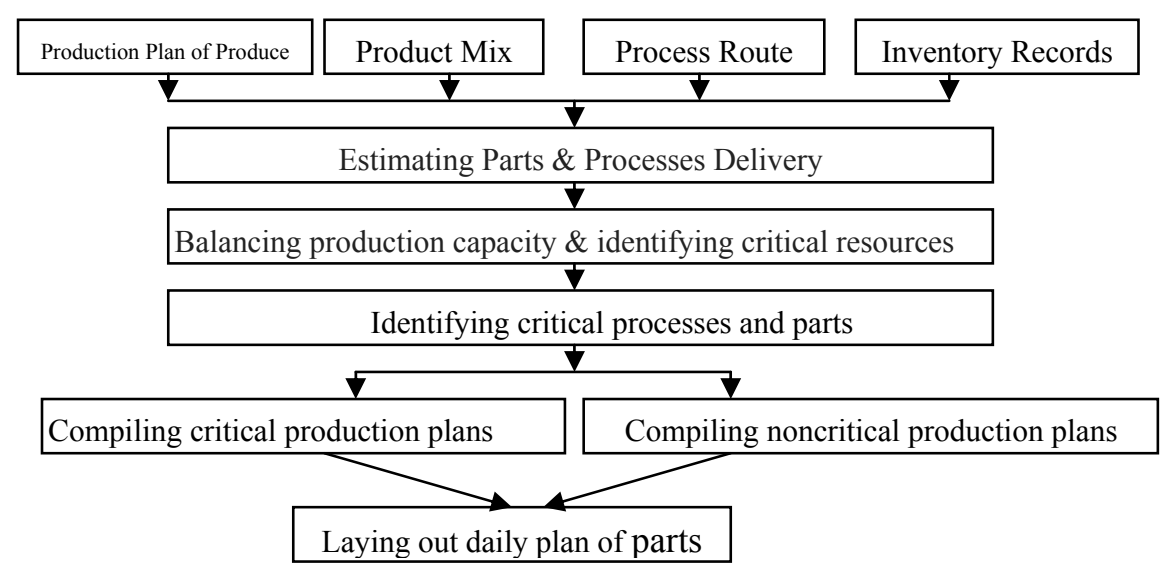

Figure 2. The process of the compilation of production plan

\subsubsection{Estimating Parts \& Process Delivery}

Estimation of parts and processes delivery is based on main production plans, product mix information, process route and inventory information. The estimation methods are as follows,

Set $T_{\mathrm{j}}^{(\mathrm{i})}$ as the delivery date of the $\mathrm{i}$-th layer of the $\mathrm{j}$-th part in the product mix, $\mathrm{t}_{\mathrm{j}}^{(\mathrm{i})}$ the production cycle of producing or assembling the part and $T_{\mathrm{kj}}^{(\mathrm{i}+1)}$ the delivery date of the k-th section of the $\mathrm{j}$-th part, so

$$
\begin{gathered}
T_{\mathrm{kj}}^{(\mathrm{i}+1)}=T_{\mathrm{j}}^{(\mathrm{i})}-\mathrm{t}_{\mathrm{j}}^{(\mathrm{i})} \\
(\mathrm{i}=0,1, \ldots, \mathrm{j}=1,2 \ldots, \mathrm{k}=1,2 \ldots)
\end{gathered}
$$

Wherein, if $t_{j}^{(i)}$ is assembly cycle, it shall include the corresponding time for assembling the parts and the transitional time among each assembly. If $t_{j}^{(i)}$ is production cycle, it shall include the transitional time among each process

Set $T_{i j}$ as the scheduled completion date of the $i$-th process of the part $j, T_{i}$ the scheduled completion date of part $j$, $t_{i j}$ the working hours rating of the $i$-th process of part $j, t_{j}$ the preparation time for processing part $j$, including processing time, transitional time for one process to the other, transportation time and inspection time. $\mathrm{Q}_{\mathrm{ij}}$ refers to the production batch of the $\mathrm{i}$-th process of the $\mathrm{j}$-th part and $\mathrm{m}$ the total number of the processes of the $\mathrm{j}$-th part. Then,

$$
T_{\mathrm{ij}}=T_{\mathrm{j}}-\sum_{\mathrm{i}=1}^{\mathrm{m}} Q_{\mathrm{ij}} \mathrm{t}_{\mathrm{ij}}-\sum_{\mathrm{i}=1}^{\mathrm{m}} \mathrm{t}_{\mathrm{i}}
$$




\subsubsection{Balancing Production Capacity \& Identifying Critical Resources}

The parts are assigned to each production unit according to their categories so as to check the load of production equipment in each production unit. The capacity is analyzed based on the actual load and the rated load to identify critical resources. The steps of analyses are as follows,

(1) To calculate the scheduled load of production equipment on a time span

(2) To set the rated capacity of the equipment as A, the scheduled load B and the assigned load C, then

If $\frac{B}{A-C} \geq 1$, the remaining capacity of the equipment in the planning period shall meet the scheduled task.

If $\frac{B}{A-C}<1$, the equipment is overloaded in planning period so measures shall be taken to ensure the completion of the scheduled task or the main production schedule shall be adjusted.

(3) On the premise of the capacity balance, the equipment with $\frac{B}{A-C}$ equal or close to 1 is defined as the critical resource of the production unit and $\frac{B}{A-C}$ is the load rate of the equipment

\subsubsection{Identifying Critical Processes and Parts}

The step of processing on the critical resource is defined as a critical process and the part with the critical process a critical part

\subsubsection{Compiling Critical Production Plans}

(1) For each critical equipment, the process with the latest delivery date is picked out from all critical processes with the equipment and its start date and completion date are set.

(2) With the start date and the completion date of the above process as a reference, according to the sequence of the delivery dates of every critical process on the equipment, with the planning method of limited capacity and inverted method, the start date and the completion date of each critical process shall be defined preliminarily.

(3) The normal process before the critical one shall be inverted sequentially from back to front with the critical process as a benchmark according to the scheduled principle of the pull model.

(4) The normal process after the critical one shall be inverted sequentially from front to back with the critical process as a benchmark according to the scheduled principle of the drive model.

(5) When the ultimate completion date of several parts is beyond the specified delivery date in the plan, the sequence of the parts on the critical equipment shall be adjusted so as to strive to eliminate or minimize the loss of delaying the work.

(6) If the scheduled task is not aligned with the assigned one on the equipment, the chronological order on the critical equipment shall be adjusted so that the critical equipment is made not to be idle.

\subsubsection{Compiling Noncritical Production Plans}

The production plan of critical parts shall meet the two demands of producing them to sets and balancing production load and production capacity. Therefore, the compilation of the production plan of non-critical parts shall be to define the sequence of production and weekly production list but the specific production date and the specific schedule are set by daily plan.

(1) Sequence of production

If the production cycle of the parts is less than a week, the early delivery date shall be produced early and vice versa. If the delivery dates of two parts are same, according to the production cycle, the production of the part with short production cycle comes first, after, it with long production cycle is assigned.

If the production cycle of the parts is more than a week, the production shall be assigned according to the sequence of the spare time on the production schedule.

Spare time of part $\mathrm{j}$ on production schedule $\mathrm{K}_{\mathrm{j}}=\frac{\text { Scheduled period of part } j}{\text { Production cycle of part } j}$ 
Scheduled period of part $\mathrm{j}=\mathrm{its}$ scheduled delivery date - the scheduled start date

If $\mathrm{k}_{\mathrm{j}}<2$, according to the production cycle of parts, the sequence is made from small to large. If the production cycle of the two parts is same, the production with the early delivery date comes first.

If $\mathrm{k}_{\mathrm{j}} \geq 2$, according to the production cycle of parts, the sequence is made from large to small. If the production cycle of the two parts is same, the production with the early delivery date comes first.

(2) Setting the parts of weekly production in scheduled period. According to the set sequence of parts production, the production cycle of each part is accumulated one by one from front to back and the parts of weekly production shall be defined.

Set $\mathrm{L}_{\mathrm{wi}}$ as accumulated working hours of parts in the i-th week with the accumulated production cycle $\mathrm{t}$ of parts so the following equation is

$$
\begin{gathered}
L_{\mathrm{w} 1}=\sum_{\mathrm{j}=1}^{\mathrm{n}_{1}} \mathrm{t}_{\mathrm{j}} \geq \mathrm{c}_{\mathrm{w}}, \sum_{\mathrm{j}=1}^{\mathrm{n}_{1}-1} \mathrm{t}_{\mathrm{j}}<\mathrm{c}_{\mathrm{w}} \\
L_{\mathrm{w} 2}=\sum_{\mathrm{j}=1}^{\mathrm{n}_{2}} \mathrm{t}_{\mathrm{j}} \geq 2 \mathrm{c}_{\mathrm{w}}, \sum_{\mathrm{j}=1}^{\mathrm{n} 2-1} \mathrm{t}_{\mathrm{j}}<2 \mathrm{c}_{\mathrm{w}} \\
L_{\mathrm{wk}}=\sum_{\mathrm{j}=1}^{\mathrm{n}_{\mathrm{k}}} \mathrm{t}_{\mathrm{j}} \leq \mathrm{kc} \mathrm{c}_{\mathrm{w}}
\end{gathered}
$$

So, in the first week, the parts which shall be produced are $1 \sim \mathrm{n}$; in the second week, they $\mathrm{n}_{1} \sim \mathrm{n}_{2}$, and so on. Until the k-th week, all parts shall be produced

\subsubsection{Laying Out Daily Plan of Parts}

Daily production plan is the basis of the production plan. For single and small batch production, daily production plan refers to two-day rolling plan, which depends on the three aspects: the first is the plan of critical parts, which ensures the completion of critical parts plan; the second is the production plan of non-critical parts, which refers to the balance of load and capacity; the third is the production compilation of non-critical parts.

The following example is taken to illustrate the production preparation method of critical parts. Suppose the following definition: the production process, working hours rating and delivery dates of six parts of $\mathrm{A}, \mathrm{B}, \mathrm{C}, \mathrm{D}$,

\begin{tabular}{|c|c|c|c|c|c|c|c|c|c|c|c|c|}
\hline \multirow{2}{*}{$\begin{array}{l}\text { Part } \\
\text { name }\end{array}$} & \multirow{2}{*}{$\begin{array}{l}\text { Product- } \\
\text { ion lot }\end{array}$} & \multicolumn{10}{|c|}{ Process name and working hours rating } & \multirow{2}{*}{$\begin{array}{l}\text { Delivery } \\
\text {-date } \\
\text { of parts }\end{array}$} \\
\hline & & 1 & & 2 & & 3 & & 4 & & 5 & & \\
\hline A & 4 & Lathe & 6 & $\begin{array}{l}\text { Drilling } \\
\text { machine }\end{array}$ & 2 & Borer & 6 & Grinder & 4 & & & 480 \\
\hline B & 2 & Lathe & 3 & Lathe & 5 & $\begin{array}{l}\text { Drilling } \\
\text { machine }\end{array}$ & 4 & Borer & 7 & $\begin{array}{l}\text { Milling } \\
\text { machine }\end{array}$ & 5 & 432 \\
\hline $\mathrm{C}$ & 2 & $\begin{array}{l}\text { Milling } \\
\text { machine }\end{array}$ & 8 & $\begin{array}{l}\text { Drilling } \\
\text { machine }\end{array}$ & 4 & Borer & 8 & Grinder & 5 & & & 432 \\
\hline $\mathrm{D}$ & 4 & Lathe & 6 & $\begin{array}{l}\text { Milling } \\
\text { machine }\end{array}$ & 8 & Lathe & 4 & Borer & 8 & Grinder & 6 & 480 \\
\hline E & 6 & Lathe & 5 & $\begin{array}{l}\text { Milling } \\
\text { machine }\end{array}$ & 5 & $\begin{array}{l}\text { Drilling } \\
\text { machine }\end{array}$ & 2 & Lathe & 4 & Borer & 8 & 480 \\
\hline $\mathrm{F}$ & 4 & $\begin{array}{l}\text { Milling } \\
\text { machine }\end{array}$ & 6 & $\begin{array}{l}\text { Milling } \\
\text { machine }\end{array}$ & 8 & $\begin{array}{l}\text { Drilling } \\
\text { machine }\end{array}$ & 4 & Grinder & 6 & & & 480 \\
\hline
\end{tabular}
$\mathrm{E}$ and $\mathrm{F}$, as shown in Table 2.

Table 2. Working hours rating and of delivery date of each part

The above 6 parts shall be produced in the production unit of Group G. there are 2 lathes, 1 milling machine, borer, drilling machine and grinder respectively. If there are 6 shifts for one week, every shift with 8 hours, and delivery date of the process is 480 hours, the formula for the delivery date of the process of each part is

$$
T_{\mathrm{ij}}=T_{\mathrm{i}}-\sum_{\mathrm{i}+1}^{\mathrm{m}} Q_{\mathrm{ij}} \times \mathrm{t}_{\mathrm{ij}}-\sum_{\mathrm{i}}^{\mathrm{m}} \mathrm{t}_{\mathrm{ij}}
$$


Wherein, $T_{i j}$ is the latest delivery date of the $i$-th process of the part and $T_{j}$ the latest delivery time of part $j$.

$\sum_{\mathrm{i}+1}^{\mathrm{m}} Q_{\mathrm{ij}} \times \mathrm{t}_{\mathrm{ij}}$ is the processing time from process $(\mathrm{i}+1)$ to process $\mathrm{m}$ for producing a batch of parts $\mathrm{j}$ with $\mathrm{Q}$ as the batch. $\sum_{i}^{m} t_{i j}$ refers to the time of transportation and inspection of part $j$ from process $i$ to process $m$.

Suppose the planning period from 192 hours to start to 480 hours to end. In the previous planning period, the unfinished tasks are: 192 hours in the process of lathe, 96 hours in milling machine, 72 hours in drilling machine, 150 hours in borer and 88 hours in grinder. For simplicity, suppose the time for transporting from one process to the other and inspecting is zero, then calculate the load rate of the equipment in each interval to find bottleneck resources, as shown in Table 3.

Table 3. Calculation table of delivery time of parts and processes

\begin{tabular}{|c|c|c|c|c|c|c|c|c|c|c|c|c|c|}
\hline \multicolumn{2}{|c|}{$\begin{array}{l}\text { Serial } \\
\text { Number }\end{array}$} & \multicolumn{2}{|l|}{ A } & \multicolumn{2}{|l|}{ B } & \multicolumn{2}{|l|}{ C } & \multicolumn{2}{|l|}{$\mathrm{D}$} & \multicolumn{2}{|l|}{ E } & \multicolumn{2}{|l|}{$\mathrm{F}$} \\
\hline 1 & $\begin{array}{l}2 \\
3\end{array}$ & Lathe & $\begin{array}{l}24 \\
432\end{array}$ & Lathe & $\begin{array}{l}6 \\
369\end{array}$ & $\begin{array}{l}\text { Milling } \\
\text { machine }\end{array}$ & $\begin{array}{l}16 \\
398\end{array}$ & Lathe & $\begin{array}{l}24 \\
376\end{array}$ & Lathe & $\begin{array}{l}30 \\
366\end{array}$ & $\begin{array}{l}\text { Milling } \\
\text { machine }\end{array}$ & $\begin{array}{l}24 \\
408\end{array}$ \\
\hline 1 & $\begin{array}{l}2 \\
3\end{array}$ & $\begin{array}{l}\text { Drilling } \\
\text { machine }\end{array}$ & $\begin{array}{l}8 \\
440\end{array}$ & Lathe & $\begin{array}{l}10 \\
400\end{array}$ & $\begin{array}{l}\text { Drilling } \\
\text { machine }\end{array}$ & $\begin{array}{l}8 \\
406\end{array}$ & $\begin{array}{l}\text { Milling } \\
\text { machine }\end{array}$ & $\begin{array}{l}32 \\
408\end{array}$ & $\begin{array}{l}\text { Milling } \\
\text { machine }\end{array}$ & $\begin{array}{l}30 \\
396\end{array}$ & $\begin{array}{l}\text { Milling } \\
\text { machine }\end{array}$ & $\begin{array}{l}32 \\
440\end{array}$ \\
\hline 1 & $\begin{array}{l}2 \\
3\end{array}$ & Borer & $\begin{array}{l}24 \\
464\end{array}$ & $\begin{array}{l}\text { Drilling } \\
\text { machine }\end{array}$ & $\begin{array}{l}8 \\
408\end{array}$ & Borer & $\begin{array}{l}16 \\
422\end{array}$ & Lathe & $\begin{array}{l}16 \\
424\end{array}$ & $\begin{array}{l}\text { Drilling } \\
\text { machine }\end{array}$ & $\begin{array}{l}12 \\
408\end{array}$ & $\begin{array}{l}\text { Drilling } \\
\text { machine }\end{array}$ & $\begin{array}{l}16 \\
456\end{array}$ \\
\hline 1 & $\begin{array}{l}2 \\
3\end{array}$ & Grinder & $\begin{array}{l}16 \\
480\end{array}$ & Borer & $\begin{array}{l}14 \\
422\end{array}$ & Grinder & $\begin{array}{l}10 \\
432\end{array}$ & Borer & $\begin{array}{l}32 \\
456\end{array}$ & Lathe & $\begin{array}{l}24 \\
432\end{array}$ & Grinder & $\begin{array}{l}24 \\
480\end{array}$ \\
\hline 1 & $\begin{array}{l}2 \\
3 \\
\end{array}$ & & & $\begin{array}{l}\text { Milling } \\
\text { machine }\end{array}$ & $\begin{array}{l}10 \\
432 \\
\end{array}$ & & & Grinder & $\begin{array}{l}24 \\
480\end{array}$ & Borer & $\begin{array}{l}48 \\
480\end{array}$ & & \\
\hline
\end{tabular}

Note: 1 is the name of the process, 2 for the processing time, 3 for the process of delivery

From Table 3, in the planning period, the borer in unit $\mathrm{G}$ is a bottleneck resource and A, B, C, D and E are key parts. The parts processed on the lathe can be sequenced as follows, according to the delivery time of the process on the lathe: delivery time of B4 (the $4^{\text {th }}$ process of part B) is 422; C3 422; D4 456; A3 464 and E5 480. In the above sequence, with the method of limited capacity planning, the processes on the lathe are sequenced. There are 150 hours for unfinished task in the previous interval so the starting time for this task in the planning period is 343 hours $(192+150)$. The delivery time of B4 and C3 is same so the priority shall be defined base on other conditions. For example, the process with more steps and heavier workload at the beginning comes first or the process at the end does. On the contrary, the process with less steps and lighter workload comes second. The schedule for processing part on the bottleneck resource (lathe) shall be listed in detail in Figure 3 as follows,

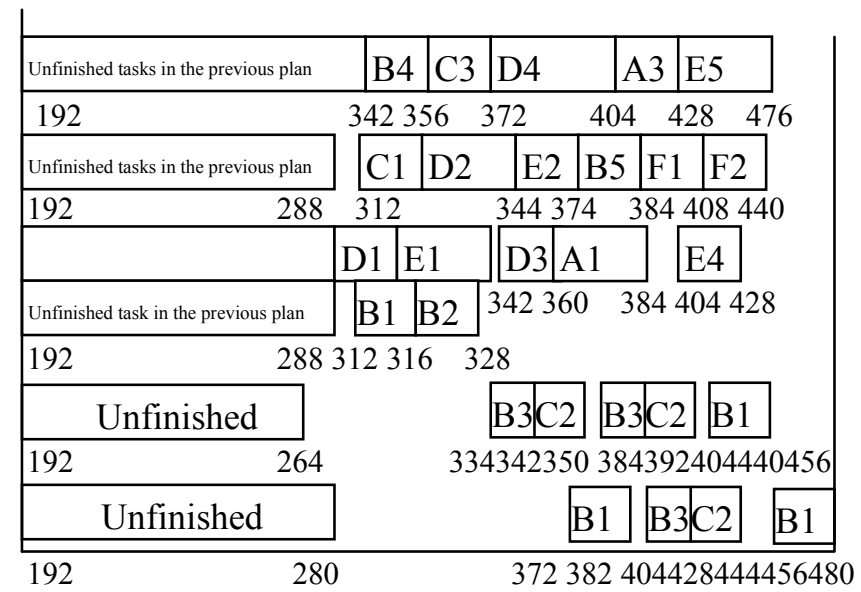

Figure 3. Schedule for processing critical parts on the bottleneck resource

Other non-critical processes of critical parts are based on critical parts. The previous processes (A1, A2, B1, B2, B3, C1, C2, D1, D2, E1, E2, E3 and E4, etc. in Figure 3) are arranged on the relevant machines according to the 
pull method from back to front. The normal processes after critical ones (such as A4, B5, C4, D5 and etc.) are arranged on the relevant machines according to the push method from front to back. So, all processes of critical parts are arranged. And so far, the production of the critical parts is scheduled.

\subsection{Setting Buffer Link - An Effective Method of Production Logistics Balance}

In order to increase the output of the entire production system and ensure the full load work of bottleneck resources, buffer link shall be set in the production system with the general "time buffer" form. Time buffer means that a buffer time shall be set from the completion time of the former process prior to bottleneck one to the beginning time of bottleneck one so as to ensure the beginning time of bottleneck one shall not be affected by the fluctuations and breakdown of the former one. In other words, the materials that are provided shall arrive ahead of the scheduled time so as to avoid the situation of work being held up for lack of material. The buffer links are set as shown in Figure 4.

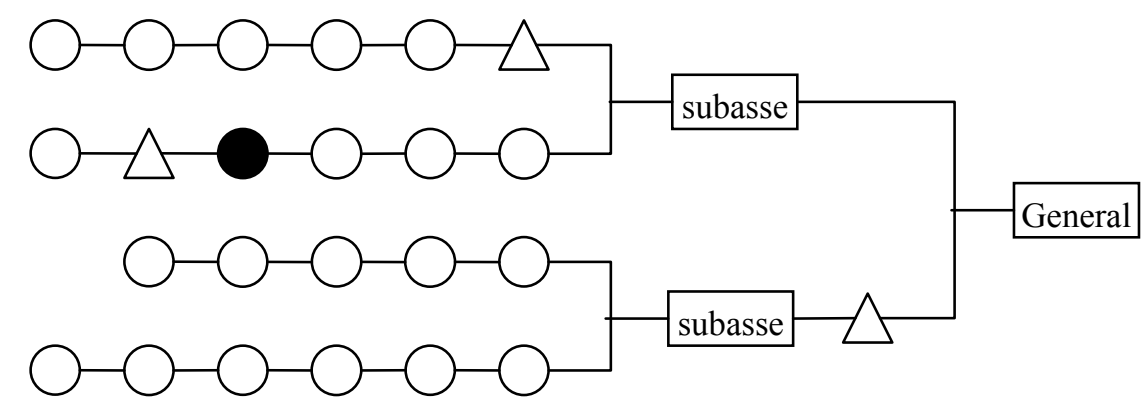

Figure 4. Diagram of setting buffer links in production system

Table 4. Calculation of load rate of equipment in each interval

\begin{tabular}{|c|c|c|c|c|c|c|c|c|}
\hline \multirow[t]{2}{*}{$\begin{array}{l}\text { Name of } \\
\text { equipment }\end{array}$} & \multirow[t]{2}{*}{ Interval } & $\begin{array}{l}\text { Extra load } \\
\text { in planning } \\
\text { period }\end{array}$ & $\begin{array}{l}\text { Extra load } \\
\text { accumulation }\end{array}$ & $\begin{array}{l}\text { Unfinis } \\
\text { load } \\
\text { former } \\
\text { week }\end{array}$ & $\begin{array}{l}\text { Total } \\
\text { in capacity } \\
\text { in tl } \\
\text { interval }\end{array}$ & $\begin{array}{l}\text { Remaining } \\
\text { capacity in } \\
\text { e the } \\
\text { interval }\end{array}$ & $\begin{array}{l}\text { Load } \\
\text { rate of } \\
\text { equipment } \\
\text { in the } \\
\text { interval }\end{array}$ & \multirow[t]{2}{*}{$\begin{array}{l}\text { Bottleneck } \\
\text { (Yes or } \\
\text { No) }\end{array}$} \\
\hline & & 1 & 2 & 3 & 4 & $5=4-3$ & $6=2 / 5$ & \\
\hline \multirow{5}{*}{$\begin{array}{l}\text { Milling } \\
\text { machine }\end{array}$} & $192-396$ & 30 & 30 & 96 & 204 & 108 & 0.278 & No \\
\hline & $192-398$ & 16 & 46 & 96 & 206 & 110 & 0.418 & No \\
\hline & $192-408$ & 56 & 102 & 96 & 216 & 120 & 0.850 & No \\
\hline & $192-432$ & 10 & 112 & 96 & 240 & 144 & 0.778 & No \\
\hline & $192-440$ & 32 & 144 & 96 & 248 & 152 & 0.947 & No \\
\hline \multirow{6}{*}{$\begin{array}{l}\text { Lathe } \\
\text { (2 sets) }\end{array}$} & $192-366$ & 30 & 30 & 192 & 348 & 156 & 0.192 & No \\
\hline & $192-376$ & 24 & 54 & 192 & 368 & 176 & 0.307 & No \\
\hline & $192-390$ & 6 & 60 & 192 & 396 & 204 & 0.294 & No \\
\hline & $192-400$ & 10 & 70 & 192 & 416 & 224 & 0.313 & No \\
\hline & $192-424$ & 16 & 86 & 192 & 464 & 272 & 0.316 & No \\
\hline & $192-432$ & 48 & 134 & 192 & 480 & 288 & 0.465 & No \\
\hline \multirow{4}{*}{ Borer } & $192-422$ & 30 & 30 & 150 & 230 & 80 & 0.375 & No \\
\hline & $192-456$ & 32 & 62 & 150 & 264 & 114 & 0.544 & No \\
\hline & $192-464$ & 24 & 86 & 150 & 272 & 122 & 0.705 & No \\
\hline & $192-480$ & 48 & 134 & 150 & 288 & 138 & 0.971 & No \\
\hline \multirow{4}{*}{$\begin{array}{l}\text { Drilling } \\
\text { machine }\end{array}$} & $192-406$ & 8 & 8 & 72 & 214 & 142 & 0.056 & No \\
\hline & $192-408$ & 20 & 28 & 72 & 216 & 144 & 0.194 & No \\
\hline & $192-440$ & 8 & 36 & 72 & 248 & 176 & 0.205 & No \\
\hline & $192-456$ & 16 & 52 & 72 & 264 & 192 & 0.271 & No \\
\hline \multirow{2}{*}{ Grinder } & $192-432$ & 10 & 10 & 88 & 240 & 152 & 0.066 & No \\
\hline & $192-480$ & 64 & 74 & 88 & 288 & 200 & 0.370 & No \\
\hline
\end{tabular}




\section{Conclusion}

Production logistics and production procedure of the enterprise are synchronized. Balance and stability of production logistics make logistics process continual, parallel, rhythmical, proportional and adaptable, more importantly, production orderly, WIP smooth flow, production cycle short, production cost decreasing and production efficiency improved. If production logistics is not balanced and stable, WIP shall be excessive with the result that the inventory and the production cost increases. It is difficult to meet the personalized demands of different customers, which makes enterprises exhausted. Therefore, planning, organization, coordination and control of production logistics process are conducted reasonably to make logistics in balance, which is a key part of the logistics management of flexible production.

\section{References}

Ahire, S.L., \& Schmidt, C.P. (1996). A model for a Mixed Continuous-Periodic Review One-Warehouse, N-Retailer inventory system. European Journal of Operational Research, 92(1), 69-82. https://doi.org/10.1016/0377-2217(94)00309-2

Ang, H. (2009, March). Optimization of Distribution system Under JIT production mode. Tianjin University of Science and Technology Thesis.

Christopher, M. (1998). Logistics \& Supply Chain Management. London: Pitman Publishing.

James, F.C., \& Michael, S.S. (1998). The Constraints Management Handbook. Port St Lucie: St Lucie Press, pp. 171-173.

Jay, H. (1999). Barry Render Production and Operations Management. Beijing: Huaxia Press, pp.145-147.

Kan, S., \& Liu, Y. (2000). Production Planning and Control System Based on OPT. Industrial Engineering and Management, 5, 45-46.

Lee, J.K., \& Larry, P.R. (2004). Foundations of Operations Management. Beijing: Chinese People's Publishing House, p.189.

Li, Q. (2007). Production and Operations Management. Beijing: Peking University Press, pp. 357-363.

Ling, L., Liu, M., \& Wang, Q. (2013). Research on Sensitivity of Material Flow Bottlenecks in Uncertain Environment of Manufacturing Plant. Agricultural Machinery, 44(2), 224-231.

Myddelton, D.R. (2001). The Essence of Operations Management. Harlow: Pearson Education Limited, pp. 35-38.

Noreen, E., Smith, D., \& Mackey, J.T. (2006). The Theory of Constraints and Its Implications for Management Accounting. New York: The North River Press, pp. 55-64.

Pan, J., \& Cao, D. (2003). Modern production management. Beijing: Tsinghua University Press, pp. 175-178.

Qi, E. (2006). Production and Operations Management . Beijing: Tsinghua University Press, pp. 192-195.

Qian, Z. (2009, June). Study on Construction and Simulation of Business Logistics System Based on Flexible Production. Jiangsu University.

Richard, B.C., \& Nicholas, J.A. (1999). Production and Operations Management: Manufacturing and Service. New York: Irwin McGraw-Hill, pp. 57-62.

Roger, G.S. (2000). Operations Management. Beijing: Peking University Press, p.161.

Wang, Y. (2002). Bottleneck management. Beijing: Mechanical Industry Press, p.107.

Xu, J., \& Guo, G. (2005). BOM Model for Material Delivery Based on Technological Process. Chongqing University (Natural Science), 6, 19-21.

Yasuhiro, M. (2012). New Toyota Production System (4 ${ }^{\text {th }}$ ed.). Wang Rui-zhu trans. Baoding: Hebei University Press.

\section{Copyrights}

Copyright for this article is retained by the author(s), with first publication rights granted to the journal.

This is an open-access article distributed under the terms and conditions of the Creative Commons Attribution license (http://creativecommons.org/licenses/by/4.0/). 